\title{
Progression of striped jack nervous necrosis virus (SJNNV) infection in naturally and experimentally infected striped jack Pseudocaranx dentex larvae
}

\author{
H. D. Nguyen, T. Nakai*, K. Muroga
}

Fish Pathology Laboratory, Faculty of Applied Biological Science, Hiroshima University, Higashihiroshima 739, Japan

\begin{abstract}
The progress of infection with SJNNV (nodavirus), the causative agent of viral nervous necrosis (VNN), was investigated by using naturally infected (acute and subacute groups) and experimentally infected striped jack larvae at different stages of infection. Although there were slight differences in the progress of infection among the 3 groups of fish examined, the general features of infection were quite similar Necrosis and vacuolation of the nerve cells were first observed in the spinal cord, particularly in the area just above the swimbladder, later in the brain, and then in the retina. Mortalities occurred 1 to $2 \mathrm{~d}$ after the commencement of lytic degeneration of the cells, which resulted in heavy vacuolation in these nervous tissues. Virus antigens were detectable in the nervous tissues by the fluorescent antibody technique (FAT) when conspicuous vacuolation appeared in the cytoplasm. Virus particles were detectable by electron microscopy in concurrence with the appearance of heavy tissue vacuolation. These results indicate that SJNNV exhibits a tropism for nerve cells and its initial multiplication site is the spinal cord, from which the virus spreads to the brain and finally to the retina. Hyperplasia was observed in the skin of 1 naturally infected larval group (acute infection) and virus multiplication was observed in these affected epithelial cells. However, the role of skin as a portal of entry for SJNNV remains unclear
\end{abstract}

KEY WORDS: Viral nervous necrosis · Nodavirus $\cdot$ Striped jack $\cdot$ In vivo multiplication

\section{INTRODUCTION}

Viral nervous necrosis (VNN) is one of the most devastating diseases of hatchery-reared larvae and juveniles of several marine fishes in Japan, e.g. Japanese parrotfish Oplegnathus fasciatus (Yoshikoshi \& Inoue 1990), redspotted grouper Epinephelus akaara (Mori et al. 1991), striped jack Pseudocaranx dentex (Mori et al. 1992, Arimoto et al. 1994), Japanese flounder Paralichthys olivaceus (Nguyen et al. 1994), kelp grouper E. moara and tiger puffer Takifugu rubripes (Nakai et al. 1994). Diseases similar to VNN have also been reported outside Japan in fish species such as barramundi Lates calcarifer (Glazebrook et al. 1990, Renault et al. 1991, Munday et al. 1992), turbot Scophthalmus maximus (Bloch et al. 1991), and sea bass

\footnotetext{
- Addressee for correspondence.

E-mail:nakaitt@ue.jpc.hiroshima-u.ac.jp
}

Dicentrarchus labrax (Breuil et al. 1991). VNN and similar diseases cause mass mortalities in larval and juvenile populations, and affected fish, particularly juvenile fish, show abnormal swimming behavior. Histopathologically, conspicuous vacuolation is observed in the spinal cord, brain, and retina, and small virus particles, 25 to $34 \mathrm{~nm}$ in diameter, are found in the cytoplasm of the affected nerve cells. None of the observed viruses had been isolated in cell cultures, but 3 viruses, striped jack nervous necrosis virus (SJNNV) (Mori et al. 1992) and fish encephalitis viruses (FEV) of barramundi and sea bass (Comps et al. 1994), were characterized using virus purified from affected fish. These have been shown to be nodaviruses (Nodaviridae) based on the properties of their coat proteins and nucleic acids and are also antigenically related (Munday et al. 1994).

In VNN of striped jack larvae, diagnostic methods such as enzyme-linked immunosorbent assay (ELISA) 
(Arimoto et al. 1992), fluorescent antibody technique (FAT) (Nguyen et al. 1994), and polymerase chain reaction (PCR) amplification (Nishizawa et al. 1994) have been developed, and the striped jack spawners were proved to be the most important source of the virus to their offspring (Arimoto et al. 1992, Mushiake et al. 1994). However, there is no detailed information available concerning the progress of infection in striped jack larvae. In the present study, the in vivo infection process of SJNNV was investigated by using naturally and experimentally infected striped jack larvae at different stages of infection.

\section{MATERIALS AND METHODS}

Naturally infected fish. Two groups of infected striped jack larvae were collected at the Komame Station of the Japan Sea-Farming Association in 1994 The first group was collected from a larval population produced by a spawning group consisting of 12 fish (6 males and 6 females). Just before spawning, the SJNNV had been detected in the reproductive fluids of 2 male and 3 female fish by a PCR amplification procedure described in previous studies (Mushiake et al. 1994, Nishizawa et al. 1994). All the larvae produced by these brood stocks died from VNN within $6 \mathrm{~d}$ of post-hatching. Fifty larvae were sampled randomly at Days $3,4,5$, and 6 post-hatching and fixed in $10 \%$ buffered formalin, of which 10 were subjected to transmission electron microscopic (TEM) examination, and the other 30 to 40 were used for a histopathological study by light microscopy (LM) and for the detection of SJNNV antigens by indirect FAT. Larval samples of the second group were the offspring of the same spawning group, which were induced to re-spawn 1 mo later. All the larvae died from VNN within $2 \mathrm{~d}$ after hatching. Fifty larvae were collected and fixed at the time of hatching (Day 0) and on Days 1 and 2 posthatching, as in the first group. These 2 groups are hereafter referred to as the subacute infection group and the acute infection group, respectively.

Experimentally infected fish. Purified SJNNV, which was previously prepared from infected striped jack larvae collected in 1993 according to the method described by Mori et al. (1992), was used as an inoculum for experimental infection. Two day old striped jack larvae ( $3.5 \mathrm{~mm}$ in total length), which were produced by SJNNV-negative spawners (VNN did not occur in this larval population), were used as test fish. Approximately 1000 larvae were kept in a 1 l sea water tank (water temperature $20^{\circ} \mathrm{C}$ ) containing $100 \mathrm{ng}$ of purified SJNNV without aeration or feeding. One hundred larvae were randomly collected and fixed with $10 \%$ buffered formalin at $12 \mathrm{~h}$ intervals until $72 \mathrm{~h}$ post-exposure. The samples were then processed as described above.

Light microscopy and fluorescent antibody technique. Formalin-fixed larvae were dehydrated through a graded series of alcohol and embedded in paraffin wax (melting point 58 to $60^{\circ} \mathrm{C}$ ). Paraffin-embedded fish were cut longitudinally at 3 to $5 \mu \mathrm{m}$ thickness, and serial sections of every fish were equally divided onto 2 sets of glass slides, one set of which was stained with hematoxylin-eosin (H\&E) and the other used for FAT.

Paraffin sections on glass slides were rehydrated through xylene and a graded series (absolute to $50 \%$ ) of alcohol. The sections were treated with $0.1 \%$ trypsin in $0.01 \mathrm{M}$ phosphate-buffered saline (PBS, pH 7.4) at $37^{\circ} \mathrm{C}$ for $30 \mathrm{~min}$ and washed with cold PBS. The samples were then incubated with an anti-SJNNV rabbit serum (1:100 dilution in PBS) at $37^{\circ} \mathrm{C}$ for $30 \mathrm{~min}$, washed with PBS and then incubated with FITCconjugated swine Ig to rabbit Ig (Dako) at $37^{\circ} \mathrm{C}$ for $30 \mathrm{~min}$. After being observed with a fluorescence microscope (Nikon EFD), these slides were washed with PBS and re-stained with H\&E for histopathological examination.

Transmission electron microscopy. Formalin-fixed samples were re-fixed in a $2.5 \%$ glutaraldehyde $/ 2 \%$ paraformaldehyde mixture ( $\mathrm{pH} 7.4)$, post-fixed with $1 \%$ osmium tetroxide and embedded in Quetol- 812 (Oken). Thin sections were stained with $1 \%$ uranyl acetate and $1 \%$ lead citrate, then examined with an electron microscope (Hitachi $\mathrm{H}-600 \mathrm{~A}$ ) at $80 \mathrm{kV}$ accelerating voltage.

\section{RESULTS}

\section{Naturally infected fish}

Acute infection

Results of LM, FAT, and TEM observation on the acute infection group are summarized in Table 1. On Day 0 post-hatching, no conspicuous histopathological changes were observed in the skin, spinal cord, brain, retina, or other tissues (gills, viscera) of any of the fish examined $(n=39)$. The necrotic degeneration of nerve cells and tissue vacuolation was first observed at a high incidence in the spinal cord $(97 \%)$, gray matter of the brain $(90 \%)$, and the retina ( $51 \%$ ) of $1 \mathrm{~d}$ old larvae examined and then in these organs of almost all $2 \mathrm{~d}$ old larvae. Particularly, the spinal cord in the area just above the swimbladder was highly affected. In addition to the histopathological changes observed in nervous tissues, hyperplasia with vacuolar degeneration of epithelial cells was seen in the epithelial layer of the 
Table 1. Examination of histopathological changes by light microscopy (LM) and detection of SJNNV by fluorescent antibody technique (FAT) and electron microscopy (TEM) in naturally and experimentally infected striped jack larvae. Results are given as numbers of positive fish among examined fish $(\mathrm{n}$ ) for necrosis and vacuolation ( $\mathrm{LM}$ ), specific fluorescence (FAT), and the presence of the virion by TEN 1 : nd: not done

\begin{tabular}{|c|c|c|c|c|c|c|c|c|c|c|c|c|c|c|c|}
\hline \multirow[t]{2}{*}{ Tissue } & \multirow[t]{2}{*}{ Method } & \multicolumn{7}{|c|}{ Natural infection (days post-hatchingl } & \multicolumn{7}{|c|}{ Experimental infection (hours post-infection) } \\
\hline & & $\begin{array}{c}0 \\
(n=39)\end{array}$ & $\begin{array}{c}\text { Acute } \\
1 \\
(n=39)\end{array}$ & $\begin{array}{c}2 \\
(n=32)\end{array}$ & $\begin{array}{c}3 \\
(n=39)\end{array}$ & $\begin{array}{c}\text { Sub } \\
4 \\
(\mathrm{n}=36)\end{array}$ & $\begin{array}{l}\text { acute } \\
\quad 5 \\
(n=30)\end{array}$ & $\begin{array}{c}6 \\
(n=30)\end{array}$ & $\begin{array}{c}0 \\
(n=32)\end{array}$ & $\begin{array}{c}12 \\
(n=42)\end{array}$ & $\begin{array}{c}24 \\
(\mathrm{n}=44)\end{array}$ & $\begin{array}{c}36 \\
(n=51)\end{array}$ & $\begin{array}{c}48 \\
(n=45)\end{array}$ & $\begin{array}{c}60 \\
(n=34)\end{array}$ & $\begin{array}{c}72 \\
(n=30)\end{array}$ \\
\hline \multirow[t]{3}{*}{ Skin } & LM & 0 & 35 & 31 & 0 & 0 & 0 & 0 & 0 & 0 & 0 & 0 & 0 & 0 & 0 \\
\hline & FAT & 0 & 39 & 32 & 0 & 0 & 0 & 0 & 0 & 0 & 0 & 0 & 0 & 0 & 0 \\
\hline & TEM & - & + & + & nd & nd & nd & nd & nd & nd & nd & nd & nd & nd & nd \\
\hline \multirow{3}{*}{$\begin{array}{l}\text { Spinal } \\
\text { cord }\end{array}$} & LM & 0 & 38 & 32 & 2 & 20 & 30 & 30 & 0 & 0 & 10 & 45 & 45 & 34 & 30 \\
\hline & FAT & 3 & 39 & 32 & 9 & 24 & 30 & 30 & 0 & 2 & 13 & 49 & 45 & 34 & 30 \\
\hline & TEM & - & + & + & - & + & + & + & nd & - & + & + & + & + & + \\
\hline \multirow[t]{3}{*}{ Brain } & LM & 0 & 35 & 32 & 0 & 10 & 28 & 30 & 0 & 0 & 3 & 35 & 40 & 34 & 30 \\
\hline & FAT & 0 & 39 & 32 & 4 & 17 & 30 & 30 & 0 & 1 & 6 & 40 & 45 & 34 & 30 \\
\hline & TEM & - & + & + & - & + & + & + & nd & - & + & + & + & + & + \\
\hline \multirow[t]{3}{*}{ Retina } & LM & 0 & 20 & 28 & 0 & 1 & 12 & 20 & 0 & 0 & 0 & 2 & 20 & 30 & 30 \\
\hline & FAT & 0 & 26 & 32 & 0 & 1 & 15 & 22 & 0 & 0 & 1 & 2 & 24 & 34 & 30 \\
\hline & TEM & - & + & + & nd & - & + & + & nd & nd & - & + & + & + & + \\
\hline
\end{tabular}

skin, gill operculum, and oral cavity in most 1 and $2 \mathrm{~d}$ old larvae. As shown in Fig. 1A, specific fluorescence, indicating the presence of viral antigens, was first detectable in the spinal cord at a position just above the swimbladder in 3 out of 39 fish examined as $0 \mathrm{~d}$ old larvae, then in all the nervous tissues and the epithelial layer of the gill operculum, the oral cavity, and the skin of $1 \mathrm{~d}$ old larvae (Fig. 2). The brightest fluorescence was detected in the spinal cord, brain, and retina of $2 \mathrm{~d}$ old larvae, while the intensity of fluorescence in the skin remained moderate.

By electron microscopy, the affected nerve cells of 1 and $2 \mathrm{~d}$ old larvae appeared highly vacuolated in their cytoplasm, in which small round-shaped virus particles assembled in a crystalline array, or in a membraneous structure, were found (Table 1, Fig. $3 \mathrm{~A}$ ), but neither prominent vacuole formation nor virus particles were found in $0 \mathrm{~d}$ old larvae. The virus particles were found most frequently in the spinal cord of individual fish, followed by brain and retina. Hyperplastic epithelial cells of 1 and 2 d old larvae were also vacuolated and virus particles were found in the cytoplasm, usually without a crystalline-array arrangement (Fig. 3B).

Fig. 1. Pseudocaranx dentex. FAT detection of SJNNV from 3 groups of infected striped jack larvae. (A) Naturally infected group (acute infection), (B) naturally infected group (subacute infection), (C) experimentally infected group. Sk: skin, Sc: spinal cord, Br: brain, Re: retina; n: number of fish examined; intensity of the fluorescence signal was given as $(+)$ weak, $(++)$ moderate, and $(+++)$ strong
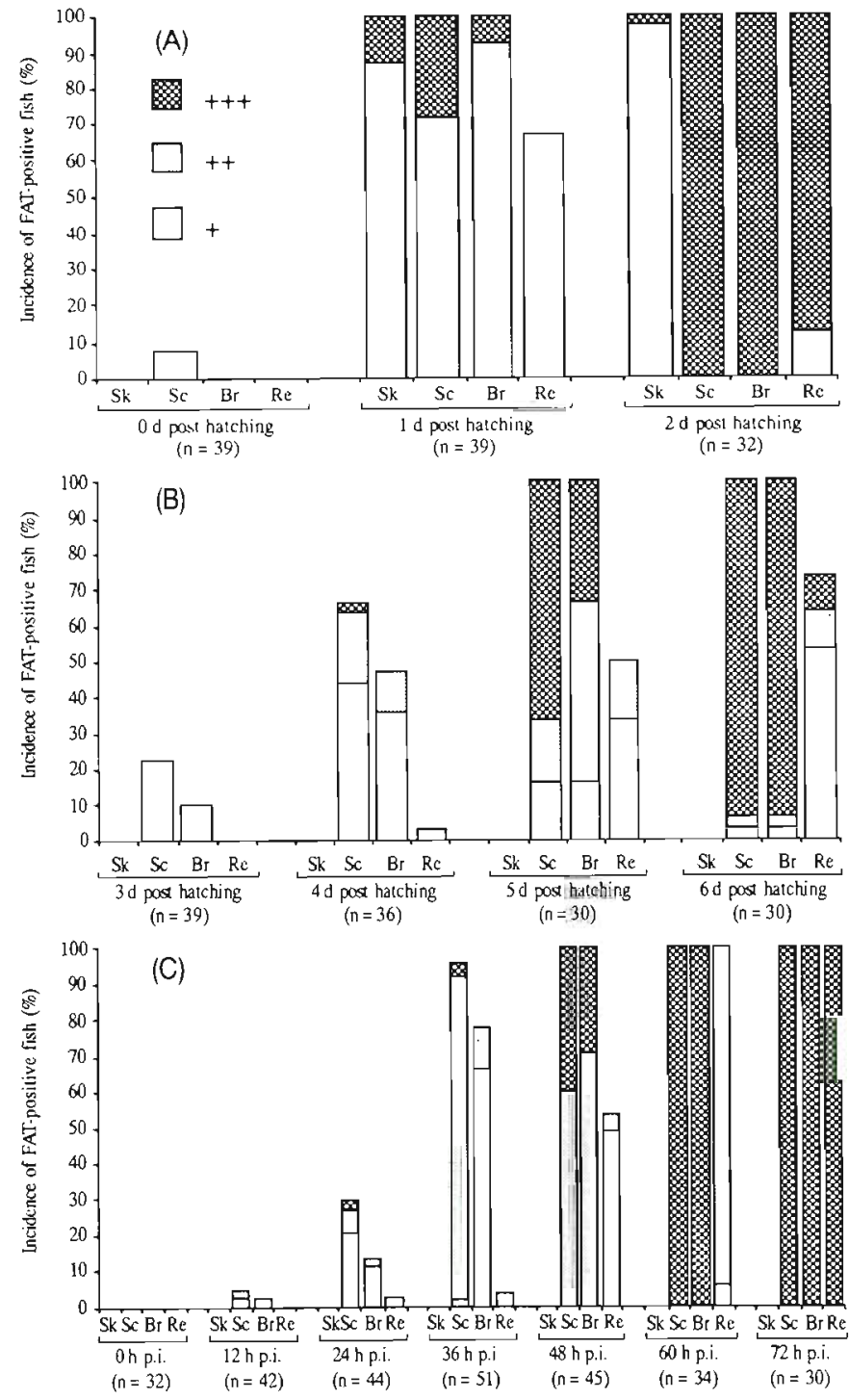


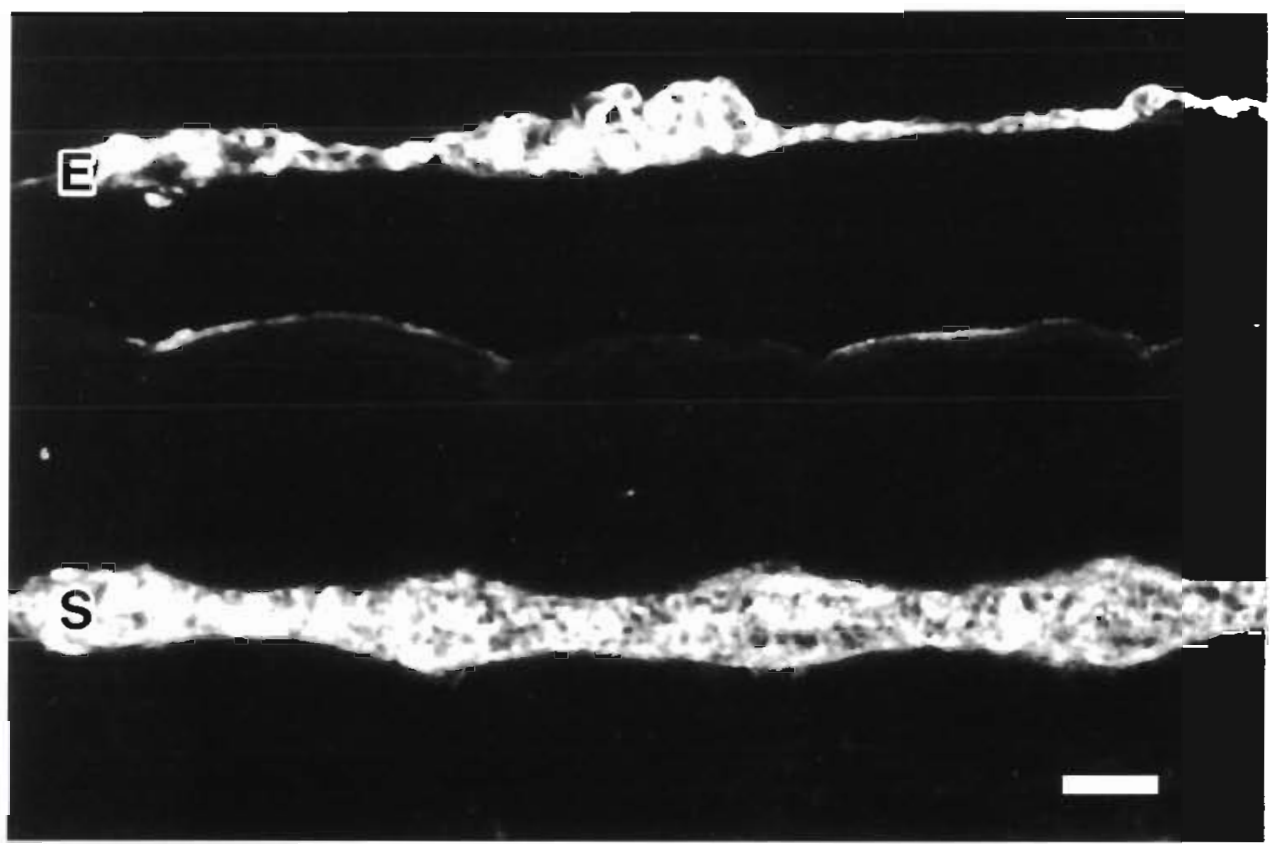

Fig. 2. Pseudocaranx dentex. Hyperplastic epidermis and vacuolated spinai cord ot a naturally infected $1 \mathrm{~d}$ old striped jack larva (acute infection group) showing specific fluorescence; S: spinal cord: E: epidermis. Scale bar $=25 \mu \mathrm{m}$
Subacute infection

Degeneration of nerve cells was only observed in the spinal cord, at a position above the swimbladder, in 2 out of 39 larvae examined on Day 3 post-hatching. On Day 4 post-hatching, cytoplasmic vacuolation was observed in the spinal cord at a high incidence (65\%), and degenerated nerve cells were seen in gray matter of the brain (28\%) and retina (3\%). In 5 and $6 \mathrm{~d}$ old fish, vacuolation was observed in the spinal cord and brain of almost all fish and in the retina at an incidence of 40 to $67 \%$. However, epidermal hyperplasia, as observed in the acute infection group, was not found in any of the fish examined in this group and no histopathological changes were observed in tissues other than those described above (Table 1).

By electron microscopy, virus particles were observed in the cytoplasm of affected nerve cells of the spinal cord and brain from $4 \mathrm{~d}$ old on and in the retinal cells of 5 and $6 \mathrm{~d}$ old fish (Table 1). Though virus particles were easily found in the cytoplasm of nerve cells in the gray matter of the brain, they were rarely observed in the white matter, usually in small numbers enclosed in a membraneous structure (Fig. 4). With the FAT, specific fluorescence was first observed in a few nerve cells of the spinal cord (23\%) and brain (10\%) of $3 \mathrm{~d}$ old larvae and in the retinal cells $(3 \%)$ of $4 \mathrm{~d}$ old larvae, and afterwards observed at high incidence in these 3 tissues of 5 and 6 d old larvae (Table 1, Fig. 1B) As shown in Fig. 1B, the strongest fluorescence was always prominent in the spinal cord followed by the brain, and the intensity and incidence in the retina were relatively low even in the terminal stage (Day 6 post-hatching). On the other hand, no specific fluorescence was observed in the skin, gills, or other internal organs.

\section{Experimentally infected fish}

All the fish experimentally exposed to the virus died by $72 \mathrm{~h}$ post-infection (p.i.). Almost the same results as those observed in the 2 naturally infected groups were obtained in these experimentally infected fish (Table 1). The necrotic degeneration of nerve cells was first observed in the spinal cord $(23 \%)$ and brain $(7 \%)$ at $24 \mathrm{~h}$ p.i., and in the retina $(4 \%)$ at $36 \mathrm{~h} \mathrm{p.i.} \mathrm{At} \mathrm{the} \mathrm{same} \mathrm{time,} \mathrm{virus} \mathrm{particles}$ were also found in the cytoplasm of nerve cells of these nervous tissues. Conspicuous vacuolation was then observed in the spinal cord and brain at $36 \mathrm{~h}$ p.i. and in the retina at $48 \mathrm{~h}$ p.i., reaching nearly $100 \%$ incidence at $72 \mathrm{~h}$ p.i. By FAT, fluorescence was first observed in the spinal cord and brain of a few fish examined at $12 \mathrm{~h}$ p.i. and in the retina at $24 \mathrm{~h}$ p.i. As shown in Fig. 1C, the fluorescence intensity as well as the incidence in FAT increased with the sampling time in the order of spinal cord, brain, and retina, and finally ( 60 and 72 h p.i.) the strongest signals were observed in these nervous tissues of all fish examined. No histopathological changes, fluorescence signals, or virus particles were observed in the skin, gills, or other internal organs throughout the course of the infection. 
Fig. 3. Pseudocaranx dentex. Electron micrographs of the affected cells of a naturally infected 1 d old striped jack larva (acute infection group). Arrows show numerous virus particles (A) in the vacuolated cytoplasm of a brain nerve cell and $(B)$ in an epithelial cell of the skin. Scale bars $=500 \mathrm{~nm}$

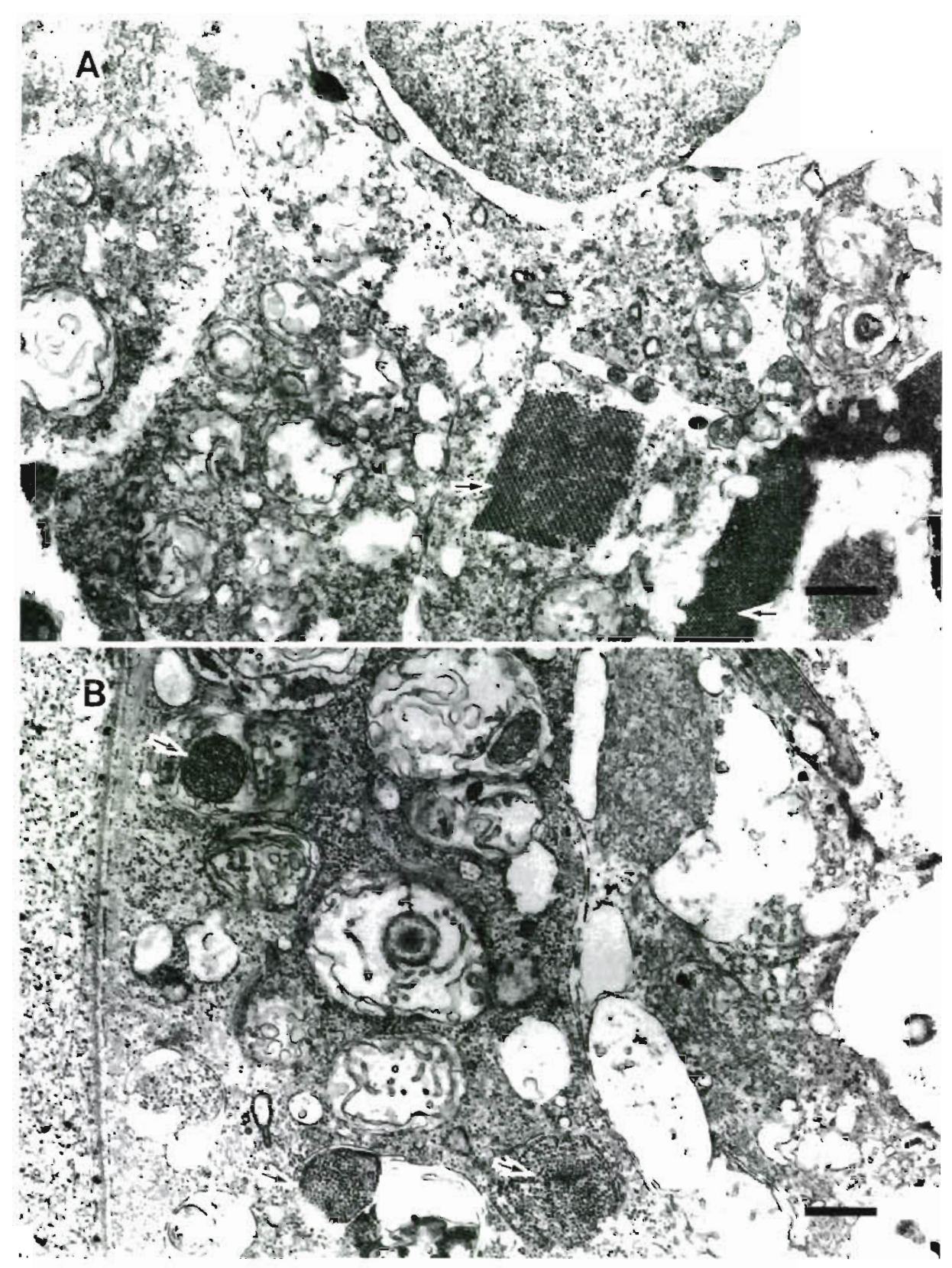

\section{DISCUSSION}

The progress of SJNNV infection was studied histopathologically using 3 groups of naturally and experimentally infected striped jack larvae. Although there were some slight differences in the progress of infection among these 3 cases, the general features of the infection were quite similar. Necrosis and vacuolation of the nerve cells were first observed in the spinal cord, particularly in the area just above the swimbladder, followed by lesions in the brain and then in the retina. Mortalities occurred 1 to 2 d after the onset of lytic degeneration of the nerve cells which resulted in the heavy vacuolation of these nervous tissues. Virus antigens were detected in the nervous tissues by FAT before conspicuous vacuolation appeared, and virus particles were observed by electron microscopy simultaneously with the appearance of conspicuous vacuolation or with a little delay. These results suggest that one of the initial multiplication sites of the virus is the spinal cord, particularly the area just above the swimbladder. From this area, the virus spreads backward to the end of spinal cord and forward to the brain and terminates in the retina. In a study on encephalomyelitis of turbot larvae, a viral disease similar to VNN, Bloch et al. (1991) found virus particles in the meningeal cells of infected 


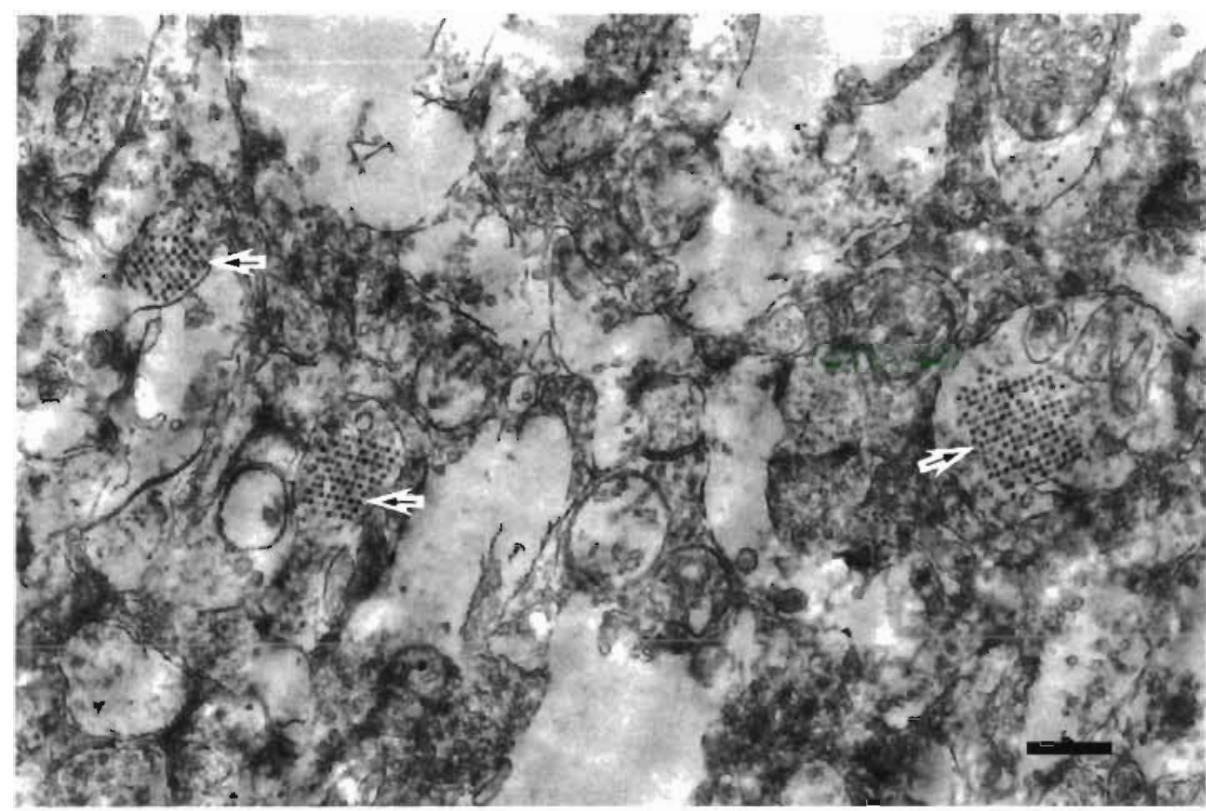

Fig. 4. Pseudocaranx dentex. Electron micrograph of the white matter of the brain in a naturally infected $5 \mathrm{~d}$ old striped jack larva (suharute infection group). The virus particles (arrows) were bound in a membrane, which was presumably a part of the nerve cells' processes. Scale bar $=$ $300 \mathrm{~nm}$

fish and suggested that cells other than neurons and glial cells can be infected. However, in our study, viruscontaining meningeal cells were not found, and the cyto-structures containing virus particles observed in the white matter of the brain appeared to be the cross sections of the nerve cells' processes.

There have been some reports on the entry and progression of pathogenic viruses in fish. Based on the results of tissue culture assays of experimentally infected carp Cyprinus carpio tissues, Ahne (1978) suggested that the portal of entry and initial multiplication site of spring viremia of carp virus (SVCV) is the gills; thereafter, the progeny virus spreads to target organs via the bloodstream. The gills were also reported to be portals of entry for viral hemorrhagic septicemia virus (VHSV) in rainbow trout Oncorhynchus mykiss (Neukirch 1984). It is likely that results of studies relating to the entry and primary replication sites of virus in host fish partly depend on the method employed. In rainbow trout infected with infectious hematopoietic necrosis virus (IHNV), the gills were suggested to be the portal of the virus based on the tissue culture assay (Yamamoto \& Clermont 1990); however, immunohistological studies revealed that the epithelium of the skin is more important as the entry site, as well as the initial replication site, than the gills (Yamamoto et al. 1990). Using tissue culture assays and immunohistological procedures, Drolet et al. (1994) reported that IHNV enters steelhead trout $O$. mykiss via the gills and gastrointestinal tract and the presence of the virus in the skin during the pre-epizootic period is a transient infection rather than a productive one. In the present study, the gills were not thought to be a portal or initial multiplication site of SJNNV in striped jack larvae, since there were neither histopathological changes nor specific fluorescent signals observed in the gills of any fish examined. An important finding in the present study is that epidermal hyperplasia was observed in the acute group of naturally infected larvae, and virus multiplication in the cytoplasm of these degenerated epidermal cells was recognized by FAT and TEM examinations. However, at the time when virus particles were found in the epidermal cells, they were also found in nerve cells of the central nervous system in larger quantities, and except in the case of the acute infection group, the virus was not detected in epithelial cells in fish of the other 2 infected larval groups. The presence of SJNNV in epithelial cells could be a result of systemic infection, or alternatively the epithelial cells might be susceptible to the virus only in the very early developmental stage of the host fish. It may be suggested that the skin is not an important portal for SJNNV. In any case, the virus must be present somewhere before its apparent multiplication in the spinal cord, either in an undetectable form or in numbers below detectable levels. Results of the FAT used in this study showed that SJNNV exhibits a specific cytotropism for nerve cells, suggesting that the virus entered the spinal cord via sensory and/or motor nerve cells linked to the epithelium. To obtain more detailed information, more sensitive methods, e.g. PCR-in situ hybridization, should be applied.

Acknowledgements. The authors thank the Japan Sea-Farming Association for kindly providing fish used in this study and for technical support in the infection experiment. This study was partially supported by a grant from the Ministry of Agriculture, Forestry and Fisheries of Japan. 


\section{LITERATURE CITED}

Ahne W (1978) Uptake and multiplication of spring viraemia of carp virus in carp. Cyprinus carpio L. J Fish Dis 1 $265-268$

Arimoto M, Maruyama K, Furusawa I (1994) Epizootiology of viral nervous necrosis (VNN) in striped jack. Fish Pathol 29:19-24

Arimoto M, Mushiake K, Mizuta Y, Nakai T, Muroga K, Furusawa I (1992) Detection of striped jack nervous necrosis virus (SJNNV) by enzyme-linked immunosorbent assay (ELISA). Fish Pathol 27:191-195

Bloch B, Gravningen K, Larsen JL (1991) Encephalomyelitis among turbot associated with a picornavirus-like agent Dis aquat Org 10:65-70

Breuil G, Bonami JR, Pépin JF, Pichot Y (1991) Viral infection (picorna-like virus) associated with mass mortalities in hatchery-reared sea-bass (Dicentrarchus labrax) larvae and juveniles. Aquaculture 97:109-116

Comps M, Pépin JF, Bonami JR (1994) Purification and characterization of two fish encephalitis viruses (FEV) infecting Lates calcarifer and Dicentrarchus labrax. Aquaculture 123:1-10

Drolet BS, Rohovec JS, Leong JC (1994) The route of entry and progression of infectious haematopoietic necrosis virus in Oncorhynchus mykiss (Walbaum): a sequential immunohistochemical study. J Fish Dis 17:337--347

Glazebrook JS, Heasman MP, de Beer SW (1990) Picorna-like viral particles associated with mass mortalities in larval barramundi, Lates calcarifer Bloch. J Fish Dis 13:245-249

Mori K, Nakai T, Muroga K, Arimoto M, Mushiake K, Furusawa I (1992) Properties of a new virus belonging to Nodaviridae found in larval striped jack (Pseudocaranx dentex) with nervous necrosis. Virology 187:368-371

Mori K, Nakai T, Nagahara M, Muroga K, Mekuchi T, Kano T (1991) A viral disease in hatchery-reared larvae and juveniles of redspotted grouper. Fish Pathol 26:209-210

Munday BL, Langdon JS, Hyatt A, Humphrey JD (1992) Mass mortality associated with a viral-induced vacuolating encephalopathy and retinopathy of larval and juvenile barramundi, Lates calcarifer Bloch. Aquaculture 103:197-211

Munday BL, Nakai T, Nguyen HD (1994) Antigenic relation-

Responsible Subject Editor: F. M. Hetrick, College Park, Maryland, USA ship of the picorna-like virus of larval barramundi, Lates calcarifer Bloch to the nodavirus of larval striped jack, Pseudocaranx dentex (Bloch \& Schneider). Aust Vet J 71. 384

Mushiake K, Nishizawa T, Nakai T, Furusawa I, Muroga K (1994) Control of VNN in striped jack: selection of spawners based on the detection of SJNNV gene by polymerase chain reaction (PCR). Fish Pathol 29:177-182

Nakai T, Nguyen HD, Nishizawa T, Muroga K, Arimoto M, Ootsuki $K$ (1994) Occurrence of viral nervous necrosis in kelp grouper and tiger puffer. Fish Pathol 29:211-212 (in Japanese)

Neukirch M (1984) An experimental study of the entry and multiplication of viral haemorrhagic septicaemia virus in rainbow trout, Salmo gairdneri Richardson, after waterborne infection. J Fish Dis 7:231-234

Nguyen HD, Mekuchi $T$, Imura $K$, Nakai $T$, Nishizawa $T$, Muroga K (1994) Occurrence of viral nervous necrosis (VNN) in hatchery-reared juvenile Japanese flounder Paralichthys olivaceus. Fish Sci 60:551-554

Nishizawa T, Mori K, Nakai T, Furusawa I, Muroga K (1994) Polymerase chain reaction (PCR) amplification of RNA of striped jack nervous necrosis virus (SJNNV). Dis aquat Org 18:103-107

Renault T, Haffner Ph, Baudin Laurencin F, Breuil G, Bonami JR (1991) Mass mortalities in hatchery-reared sea bass (Lates calcarifer) larvae associated with the presence in the brain and retina of virus-like particles. Bull Eur Ass Fish Pathol 11:68-73

Yamamoto T, Batts WN, Arakawa CK, Winton JR (1990) Multiplication of infectious hematopoietic necrosis virus in rainbow trout following immersion infection: whole-body assay and immunohistochemistry. J aquat Anim Health 2: $271-280$

Yamamoto T, Clermont TJ (1990) Multiplication of infectious hematopoietic necrosis virus in rainbow trout following immersion infection: organ assay and electron microscopy. $J$ aquat Anim Health 2:261-270

Yoshikoshi K, Inoue K (1990) Viral nervous necrosis in hatchery-reared larvae and juveniles of Japanese parrotfish, Oplegnathus fasciatus (Temminck \& Schlegel). J Fish Dis 13:69-77

Manuscript first received: June 2, 1995

Revised version accepted: A ugust 31, 1995 